\title{
ASUPAN ENERGI, PROTEIN, DAN STATUS GIZI DENGAN KADAR UREUM PADA PENDERITA PENYAKIT GINJAL KRONIK DENGAN HEMODIALISA
}

\author{
Sri Era Wahyuni, Emy Yuliantini, Desri Suryani \\ Politeknik Kesehatan Kementerian Kesehatan Bengkulu, Program Studi D-IV Gizi, \\ Jalan Indragiri Nomor 03 Padang Harapan Kota Bengkulu \\ srierawahyuni@yahoo.com
}

\begin{abstract}
Energy and protein intake decreased menurun $(<1600 \mathrm{kkal}$ and $<40 \mathrm{gr})$ in patients with CKD RSUD M.Yunus Bengkulu, which can affect the nutritional status of the state can be seen from the LLA.The purpose of this study to examine the relationship of energy intake, protein and nutritional status based on LLA with urea levels in patients with CKD undergoing hemodialysis in hemodialysis installation RSUD dr. M. Yunus Bengkulu in 2013. Type a descriptive analytic study using cross-sectional research design with the independent variables (intake of energy, protein, nutritional status) and the dependent variable (urea levels). Total population of 140 people with 58 sample was taken by purposive sampling technique. The results of this study found that there was no significant correlation between energy intake with urea levels, there was a significant association between the intake of protein with urea levels and no significant correlation between the levels of nutritional status on penderta urem CKD undergoing hemodialysis in hemodialysis Installation RSUD $\mathrm{dr}$. M. Yunus Bengkulu in 2013.
\end{abstract}

Keywords: PGK, energy intake, protein intake, LLA and urea level

\begin{abstract}
Abstrak : Asupan energi dan protein menurun ( $<1600$ kkal dan $<40$ gr) pada penderita PGK di RS UD M.Yunus Bengkulu, sehingga dapat mempengaruhi keadaan status nutrisi yang dapat dilihat dari LLA. PGK adalah keadaan dimana terjadi penurunan fungsi ginjal yang cukup berat secara perlahan-lahan yang disebabkan oleh berbagai penyakit ginjal.Tujuan penelitian ini untuk melihat hubungan asupan energi, protein dan status gizi berdasarkan LLA dengan kadar ureum pada penderita PGK yang menjalani hemodialisa di instalasi hemodialisa RSUD dr. M. Yunus Bengkulu tahun 2013. Jenis penelitian deskriptif analitik dengan menggunakan desain penelitian cross sectional dengan variabel independen (asupan energi, protein, status gizi) dan variabel dependen (kadar ureum). Jumlah populasi 140 orang dengan sampel penelitian berjumlah 58 orang yang diambil dengan teknik purposif sampling. Tidak ada hubungan yang bermakna antara asupan energi dan status gizi dengan kadar ureum, ada hubungan yang bermakna antara asupan protein dengan kadar ureum pada penderta PGK yang menjalani hemodialisa di Instalasi hemodialisa RSUD dr. M. Yunus Bengkulu tahun 2013.
\end{abstract}

Kata Kunci : Penyakit Ginjal Kronis, Asupan Energi, Asupan Protein, LLA dan Kadar Ureum

Penyakit Ginjal Kronis (PGK) merupakan permasalahan bidang nefrologi, etiologi yang luas dan kompleks, sering tanpa keluhan maupun gejala klinis kecuali sudah masuk ke stadium terminal dan disebut sebagai penyakit ginjal terminal. World Health Organization (WHO) memperkirakan setiap satu juta penduduk terdapat 25-30 orang yang mengalami Penyakit ginjal pertahun. Di Amerika Serikat (1995-1999) menyatakan insiden PGK diperkirakan 100 kasus perjuta penduduk pertahun dan angka ini meningkat sekitar $8 \%$ setiap tahunnya. Di negaranegara berkembang lainnya, insiden ini diperkirakan sekitar 40-60 kasus perjuta penduduk pertahun. Dari data dibeberapa 
pusat nefrologi di Indonesia diperkirakan insiden dan prevalensi PGK adalah sekitar 2000 per juta penduduk.

Pasien yang sudah sampai pada tahap penyakit ginjal terminal, harus melakukan terapi antara lain hemodialisa (HD), peritoneal dialisis dan transplantasi ginjal. HD adalah terapi pengganti yang paling banyak digunakan karena efektif mengeluarkan cairan dan sisa-sisa metabolisme (Rahardjo, 2001). Di Indonesia, peningkatan jumlah penderita penyakit ginjal bisa dilihat dari data kunjungan ke poli ginjal dan banyaknya penderita yang menjalani hemodialisa (Suwitra, 2006).

Berdasarkan sebuah penelitian klinik menunjukkan bahwa pasien HD yang mengkonsumsi energi dan protein dibawah nilai cut of threshold, yaitu asupan protein dibawah $0,8 \mathrm{gr} / \mathrm{kgBB} / \mathrm{hr}$ dan asupan energi di bawah $25 \mathrm{kkal} / \mathrm{kgBB} / \mathrm{hr}$ tidak bisa mempertahankan keseimbangan ureum (Nugrahani, 2007)

Kelainan gizi yang terjadi pada PGK yang menjalani HD berupa malnutrisi energi dan protein, dimana terjadi kehilangan protein dalam tindakan dialisis, bila hal ini tidak ditanggulangi dengan baik, maka akan menyebabkan gangguan status gizi (Yunita, 2008).

Status gizi pada penderita PGK yang menjalani HD dapat dilakukan antara lain dengan pengukuran antropometri yaitu salah satunya dengan pengukuran lingka lengan atas (LLA) (Nur, 2008). Tujuan pengukuran LLA pada pasien tersebut adalah untuk melihat cadangan otot pasien, karena pada penderita PGK yang menjalani terapi HD banyak menyebabkan terjadi kehilangan massa otot, yang merupakan salah satu indikator terjadinya malnutrisi pada pasien PGK. Pada pasien HD keadaan malnutrisi lebih dipersempit dengan melihat terjadinya deplesi dari cadangan protein yang terdapat dalam tubuh pasien (Yunita, 2008).

Hasil akhir dari metabolisme protein salah satunya adalah ureum, yang normalnya diekskresikan melalui urin. Kadar ureum dalam darah dipengaruhi oleh jumlah asupan protein dan katabolisme protein (Price dan Wilson, 2006).

Kesehatan fungsi ginjal salah satunya dapat dideteksi dari kadar ureum dalam darah. Makin tinggi kadar ureum tersebut berarti makin besar kemungkinan terjadinya gangguan atau kegagalan fungsi ginjal, karena menunjukkan bahwa kemampuan ginjal mengeluarkan zat tersebut sudah mulai berkurang (Suhardjono, 2001).

Semakin tinggi asupan protein maka akan semakin tinggi kadar ureum penderita PGK yang menjalani HD di instalasi hemodialisa RSUD dr. M. Yunus Bengkulu. Ratarata asupan protein pada penderita PGK adalah 48,37 gr dengan hasil rata-rata kadar ureum darahnya $111,79 \mathrm{mg} / \mathrm{dl}$ ( Meliyani, 2010).

Hasil survey awal yang dilakukan pada 10 pasien PGK yang menjalani HD di instalasi hemodialisa, diantaranya 5 orang laki-laki dan 5 orang perempuan. Enam dari sepuluh responden tersebut asupan energinya $<1600 \mathrm{kkal}$, protein < 40 gr dan status gizi berdasarkan LLA baik laki-laki maupun perempuan kurang dari normal dengan kadar ureum > dari $100 \mathrm{mg} / \mathrm{dl}$. empat dari sepuluh responden asupan energinya > $1600 \mathrm{kkal}$, protein $>40$ gr dan status gizi berdasarkan LLA 3 orang kurang dari normal, 1 orang lebih dari normal.

Tujuan penelitian ini untuk mengetahui hubungan asupan energi, protein dan status gizi berdasarkan LLA dengan kadar ureum pada penderita PGK yang menjalani HD di Instalasi Hemodialisa RSUD dr. M. Yunus Bengkulu tahun 2013.

\section{BAHAN DAN CARA KERJA}

Penelitian ini merupakan penelitian deskriptif analitik dengan pendekatan cross sectional. Populasi dalam penelitian ini seluruh penederita PGK yang menjalani Hemodialisa di Instalasi Hemodialisa RSUD dr. M. Yunus Bengkulu yaitu 140 orang, sedangkan sampel berjumlah 58 orang yang di ambil secara purposif sampling. Data dianalisa secara univariat dan bivariat. 
HASIL

\section{Analisa Univariat}

Tabel 1 Distribusi Asupan Energi, Protein, LLA dan kadar Ureum Pada Penderita Penyakit Ginjal Kronik yang Menjalani Hemodialisa

\begin{tabular}{lcccccc}
\hline Variabel & N & Mean & Median & SD & Min & Max \\
\hline $\begin{array}{l}\text { Asupan } \\
\text { energi }\end{array}$ & 58 & 1401.6 & 1394.5 & 293.271 & 827 & 2071 \\
$\begin{array}{l}\text { Asupan } \\
\text { protein }\end{array}$ & 58 & 50.29 & 46.5 & 15.015 & 31 & 91 \\
LILA & 58 & 25.62 & 25.0 & 3.281 & 20 & 38 \\
Ureum & 58 & 138.19 & 132.5 & 42.890 & 63 & 230 \\
\hline
\end{tabular}

Rata-rata asupan energi per hari penderita PGK yang menjalani hemodialisa di RSUD dr. M.Yunus Bengkulu adalah 1401.6 Kal. Asupan energi tertinggi pada pasien PGK adalah 2071 Kal dan asupan energi terendah adalah $827 \mathrm{Kal}$. Sedangkan untuk rata-rata asupan protein pasien PGK adalah 50.29 gr, dengan asupan protein pasien PGK tertinggi yaitu sebesar 91 gr dan asupan protein terendah yaitu 31 gr.

Rata-rata LLA penderita PGK di Instalasi Hemodialisa RSUD dr. M.Yunus Bengkulu adalah $25.62 \mathrm{~cm}$, dengan nilai LLA tertinggi yaitu $38 \mathrm{~cm}$ dan nilai terendahnya adalah $20 \mathrm{~cm}$. Sedangkan untuk rata-rata kadar ureum penderita PGK yang menjalani hemodialisa adalah $138.19 \mathrm{mg} / \mathrm{dl}$, dengan ukuran maksimal ureum $230 \mathrm{mg} / \mathrm{dl}$ dan ureum terendah $63 \mathrm{mg} / \mathrm{dl}$.

\section{Analisa Bivariat}

Analisis hubungan asupan energi dengan kadar ureum digunakan uji korelasi dapat dilihat pada tabel 2 .

Tabel 2 Analisis Hubungan Asupan Energi, Protein dan Status Gizi denganKadar Ureum pada Penderita PGK yang menjalani HD

\begin{tabular}{lccc}
\hline \multicolumn{1}{c}{ Variabel } & $\begin{array}{c}\text { Correlation } \\
\text { coefficient } \\
\text { (nilai r) }\end{array}$ & P Value \\
\hline $\begin{array}{l}\text { Asupan energi dengan } \\
\text { kadar ureum } \\
\text { Asupan protein dengan } \\
\text { kadar ureum }\end{array}$ & 0.048 & 0.722 \\
$\begin{array}{l}\text { Status gizi berdasarkan } \\
\text { LLA dengan kadar ureum }\end{array}$ & 0.061 & $0.013^{*}$ \\
${ }^{*} p<0,05$ & & \\
\end{tabular}

Berdasarkan hasil uji statistik spearman correlation pada tabel 2 didapatkan artinya tidak ada hubungan yang bermakna antara asupan energi dengan kadar ureum (pvalue $=0,722>0,05$ ). Serta tidak ada hubungan yang bermakna antara status gizi berdasarkan LLA dengan kadar ureum( $\mathrm{p}$ value $=0.648>0,05)$. Tetapi ada hubungan yang bermakna antara asupan protein dengan kadar ureum, hal ini ditunjukkan oleh pvalue $(0,013)<0,05$.

\section{PEMBAHASAN}

\section{Asupan Energi dan Kadar Ureum}

Hasil analisa hubungan asupan energi dengan kadar ureum darah pada penelitian menunjukkan penderita dengan kadar ureum tinggi berasal dari penderita yang memiliki asupan energi kurang dari kebutuhan. Berdasarkan dari hasil analisis uji spearman correlation, $\mathrm{p}$ value $=(0,722)>0,05$ yang berarti tidak ada hubungan yang signifikan antara asupan energi dengan kadar ureum pada penderita PGK yang menjalani hemodialisa di RSUD dr. M.Yunus Bengkulu.

Hasil penelitian ini sejalan dengan penelitian yang dilakukan oleh Nugrahani (2007) yang menyatakan tidak ada hubungan yang bermakna antara asupan energi dengan kadar ureum pada pasien GGK yang menjalani HD di RSUP dr. Sardjito Yogyakarta.

Untuk mempertahankan status gizi yang baik, asupan protein dan energi harus dapat memenuhi kebutuhan. Jika persediaan energi tidak mencukupi maka akan terjadi katabolisme jaringan sehingga banyak buangan nitrogen ke dalam sirkulsi darah, selanjutnya akan memperburuk keadaan uremia. Pada pasien yang asupan energi mencukupi $35 \mathrm{kal}$ atau lebih mempunyai keseimbangan positif. Kebutuhan energi dicukupi dari karbohidrat sebesar 55-60\% (Kresnawan, 2005)

\section{Asupan Protein dengan Kadar Ureum}

Hasil analisis hubungan asupan protein dengan kadar ureum darah pada penelitian ini menunjukkan bahwa semakin bertambah 
asupan protein maka kadar ureumnya juga semakin meningkat. Hasil ini diperkuat oleh analisis uji statistik spearman correlation, dengan $\mathrm{p}$ value $=0,013<0,05$ yang berarti ada hubungan yang signifikan antara asupan protein dengan kadar ureum pada penderita PGK yang menjalani hemodialisa di RSUD dr. M.Yunus Bengkulu. Nilai $r$ pada penelitian ini adalah 0,326, dapat diasumsikan bahwa mempunyai kekuatan hubungan yang sedang dan arah hubungan positif, artinya semakin banyak asupan protein maka kadar ureum penderita PGK semakin tinggi.

Hasil penelitian ini sejalan dengan penelitian yang dilakukan oleh Nugrahani (2007) menunjukkan bahwa ada hubungan yang bermakna antara asupan protein dengan kadar ureum pada pasien GGK yang menjalani HD di RSUP dr. Sardjito Yogyakarta. Hal ini juga didukung oleh penelitian Bintanah, S (2013) dimana hasil uji statistik menunjukkan ada hubungan asupan protein dengan kadar ureum pendrita GGK dengan HD Rawat Jalan di RS .Tugurejo Semarang.

Ureum merupakan produk nitrogen terbesar yang dikeluarkan melalui ginjal yang berasal dari makanan dan protein endogen yang telah difiltrasi oleh glomeruli. Konsentrasi ureum dalam cairan tubuh meningkat ketika laju filtrasi menurun. Konsentrasi ureum dalam darah juga tergantung pada intake nitrogen dan keseimbangan antara sintesis protein dalam tubuh serta gangguan yang terjadi dalam tubuh. Pada kondisi hiperkatabolisme (seperti setelah terjadi trauma yang kuat, sepsis) produksi ureum sangat meningkat (Suhardjono,2001).

Kadar ureum dalam darah dapat disebabkan oleh intake energi dan protein yang berlebihan, perdarahan gastro intestinal, hiperkatabolik, obat kortikosteroid tetrasiklin, disfungsi hati, dan malnutrisi protein. Ureum yang tinggi menyebabkan terjadinya toksin, gejalanya seperti sakit kepala, mual muntah, lemah dan biasanya ada perasaan tidak enak, lesu, gatal-gatal dan kecendrungan terjadinya perdarahan (Djarwoto, 2007).

Ureum merupakan sisa dari metabolisme protein, ureum dipengaruhi oleh jumlah protein dalam diet, fungsi residual renal, efisiensi HD, dan katabolisme. Melalui Hemodialisa ureum dibuang, pemeriksaan ureum sering dipakai untuk menilai hubungan faal ginjal dengan diet yang diberikan kepada pasien. Beberapa penelitian menunjukkan adanya hubungan antara konsumsi protein yang ditunjukkan dengan nilai rata-rata ureum. Tingginya kadar ureum juga bisa disebabkan karena fungsi ginjal menurun yang menyebabkan tidak semua limbah nitrogen dapat diekskresi. Akibatnya akan terjadi akumulasi limbah nitrogen dalam tubuh mengakibatkan peningkatan kadar ureum darah (Martini, 2010).

\section{Status Gizi Berdasarkan LLA dan Kadar Ureum}

Hasil penelitian ini menunjukkan bahwa rata-rata LLA penderita PGK yang menjalani hemodialisa di RSUD dr. M. Yunus Bengkulu yaitu 25,62 cm. Jika dibandingkan dengan standar LLA, ternyata rata-rata LLA penderita PGK sudah sesuai dengan standar.

Berdasarkan hasil analisis uji speaman correlation, $p$ value $=0,648>0,05$ yang berarti tidak ada hubungan yang signifikan antara status gizi dengan kadar ureum pada penderita PGK yang menjalani hemodialisa di RSUD dr. M.Yunus Bengkulu.

Hasil penelitian ini sejalan dengan penelitian yang dilakukan oleh Chadijah (2010) menunjukkan bahwa tidak ada hubungan antara status gizi (LLA) dengan kadar ureum darah dan kreatinin pada PGK yang menjalani HD di RSUD dr. Zainul Abidin Banda Aceh.

Mengukur keadaan malnutrisi pada penderita PGK dianjurkan melihat beberapa parameter, salah satunya adalah antropometri dengan menggunakan pengukuran LLA. Pengukuran LLA dapat memperoleh gabaran tentang keadaan massa otot. Diasumsikan pada penderita PGK, dalam waktu panjang akan kehilangan jaringan otot (Chadijah, 2010).

Status gizi berdasarkan LLA dapat menentukan cadangan protein tubuh, karena $60 \%$ protein terdapat dalam otot (Daldiyono dan Thaha, 1998). LLA yang rendah me- 
nunjukkan cadangan protein otot defisit (Nur, 2008). Protein dapat digunakan sebagai sumber energi bagi tubuh, bila energi yang berasal dari karbohidrat dan lemak tidak tercukupi (Yunita, 2008). Jika persediaan energi tidak mencukupi maka akan terjadi katabolisme jaringan sehingga banyak nitrogen dalam sirkulasi darah, selanjutnya akan mempengaruhi kadar ureum (Kresnawan, 2005 ). Menurut Rodwell (2003), ureum merupakan produk akhir katabolisme nitrogen yang utama pada manusia.

\section{KESIMPULAN}

Rata-rata asupan energi, protein masih kurang dari kebutuhan dan rata-rata status gizi berdasarkan LLA, normal pada pen-

\section{DAFTAR RUJUKAN}

Chadijah, S. (2010) Perbedaan Status Gizi, Ureum dan Kreatinin pada Pasien Gagal Ginjal Kronik dengan Diabetes Melius dan Non Diabetes Melitus di RSUD dr. Zainoel Abidin Banda Aceh, Aceh

Daldiyono dan Thaha, AR. (1998) Kapita Selekta Nutrisi Klinik, Pernepri, Jakarta, hal 6

Djarwoto, B. Anatomi-Fisiologi Ginjal, Pengertian Klasifikasi \& Etiologi PGK. Short Course Ginjal 10-12 April 2007. Minat Utama Gizi dan Kesehatan IKM FK UGM Yogyakarta

Kresnawan T. (2005) Penatalaksanaan Diet Pada Penyakit Ginjal Kronis. Disampaikan pada Pertemuan Ilmiah Nasional II AsDi Bandung 18-19 Februari 2005.

Martini, dkk (2010) Hubungan Tingkat Asupan Protein dengan Kadar Ureum dan Kreatinin Darah pada Penderita Gagal Ginjal Kronik di RSUD dr. Moewardi Surakarta, Surakarta

Meliyani, A. (2010) Hubungan Asupan Protein dengan Kadar Ureum dan Kreatinin pada Penderita Penyakit Gagal Ginjal Kronik di RSUD dr. M. Yunus Bengkulu, Bengkulu.

Nugrahani, A. (2007) Hubungan Asupan Protein Terhadap Kadar Urea Nitrogen, Kreatinin dan Albumin Dara Pasien Penyakit Ginjal Kronik derita PGK yang menjalani HD. Rata-rata kadar ureum tinggi pada PGK yang menjalani HD. Tidak ada hubungan yang bermakna asupan energi dengan kadar ureum penderita PGK yang menjalani HD. Ada hubungan yang bermakna asupan protein dengan kadar ureum penderita PGK yang menjalani HD. Tidak ada hubungan yang bermakna status gizi dengan kadar ureum penderita PGK yang menjalani HD. Hasil penelitian mengharafkan pihak institusi RS untuk mengembangkan formula makanan yang dapat meningkatkan asupan zat gizi penderita GGK dan perlu dilanjutkan penelitiaan untuk melihat daya terima dari formula tersebut.

yang Menjalani Hemodialisa di RSUP DR. Sardjio Yogyakarta, Yogyakarta

Nur, E (2008) Hubungan Asupan Zat Gizi dan Status Gizi Dengan Kualitas Hidup Penderita Penyakit Ginjal Kronik Yang Menjalani Hemodialisis Di RSUD Dr. M.Yunus Bengkulu, Bengkulu.

Price SA, Wilson LM, Phathophysiologi, Clinical Concept of Disease Processes, Edisi 6 (2003), Hartanto H, Penerjemah, 2005. Patofisiologi, Konsep Klinis Proses-preses Penyakit. EGC, Jakarta

Rahardjo, P. (2001) Dialisis dalam Buku Ajar Ilmu Penyakit Dalam, jilid 2 Edisi 3. Balai Penerbit FKUI, Jakarta.

Rodwell, VW. (2003) Katabolisme Protein dan Nitrogen Asam Amino dalam Biokimia Harper. Edisi 25. EGC, Jakarta, hal 303

Suhardjono, (2001) Gagal Ginjal Kronik dalam Buku Ajar Ilmu Penyakit Dalam, jilid 2 Edisi 3. Balai Penerbit FKUI, Jakarta.

Yunita, Novi. (2008) Hubungan Asupan Energi, Protein dan Kadar Kreatinin Pada Pasien Hemodialisa Di Yayasan Ginjal Diatrans Indonesia, Jakarta. 